\title{
Detoxification of hydrogen peroxide and expression of catalase genes in Rhodobacter
}

\author{
Correspondence \\ Gabriele Klug \\ Gabriele.Klug@mikro.bio. \\ uni-giessen.de
}

Received 6 May 2004

Revised 22 July 2004

Accepted 25 July 2004

\author{
Tanja Zeller and Gabriele Klug
}

Institut für Mikrobiologie und Molekularbiologie, University of Giessen, Heinrich-Buff-Ring 26-32, D-35392 Giessen, Germany

\begin{abstract}
The two related facultatively photosynthetic bacteria Rhodobacter sphaeroides and Rhodobacter capsulatus show different sensitivities against peroxide stress. $R$. sphaeroides is able to tolerate higher concentrations of $\mathrm{H}_{2} \mathrm{O}_{2}$ and exhibits higher catalase activity than $R$. capsulatus. The katE gene of $R$. sphaeroides and the kat $G$ gene of $R$. capsulatus are strongly induced by $\mathrm{H}_{2} \mathrm{O}_{2}$. This induction depends on the presence of the OxyR protein, which is able to bind to the promoter regions of these genes. In addition to katE $R$. sphaeroides harbours the katC gene, which shows no significant response to $\mathrm{H}_{2} \mathrm{O}_{2}$ but is induced in stationary phase.
\end{abstract}

\section{INTRODUCTION}

The production of reactive oxygen species (ROS) is an inherent consequence of an aerobic lifestyle for living organisms. Well-balanced defence systems are required to guarantee survival of aerobically living cells by removing ROS (Storz \& Zheng, 2000), keeping the cellular environment reduced, and repairing oxidation-generated damage. Most organisms that can grow in the presence of oxygen harbour catalases and/or peroxidases which scavenge the $\mathrm{H}_{2} \mathrm{O}_{2}$ that is produced endogenously by the respiratory chain or is generated in the environment. $\mathrm{H}_{2} \mathrm{O}_{2}$ can damage enzymes by oxidizing thiol groups and iron-sulfur centres, and by conversion to hydroxyl radicals it can produce mutagenic and lethal lesions (Storz \& Imlay, 1999). Two types of catalase, Mn-catalase and haem catalase, are presently known (Ueda et al., 2003), which catalyse the destruction of $\mathrm{H}_{2} \mathrm{O}_{2}$ with very high $K_{\text {cat }} / K_{\mathrm{s}}$ values to ensure rapid removal of these reactive molecules. $\mathrm{H}_{2} \mathrm{O}_{2}$ detoxification in Escherichia coli is mainly due to two distinct types of catalase. The $k a t G$ gene encodes a bifunctional catalase hydroperoxidase I (HPI) that harbours both catalase and peroxidase activity. HPI is transcriptionally induced by the positive activator OxyR, which directly senses oxidative stress (González-Flecha \& Demple, 1997). The katE gene encodes the monofunctional HPII (which harbours only catalase activity) and its transcription requires a functional rpoS gene, which is activated in stationary-phase cells or upon various types of starvation (González-Flecha \& Demple, 1997). OxyR is not involved in the regulation of katE in E. coli (Schellhorn, 1994).

Bacteria of the genus Rhodobacter are facultatively photosynthetic bacteria. At low oxygen tension the formation of photosynthetic complexes is induced, which allows the

Abbreviation: ROS, reactive oxygen species. bacteria to perform anoxygenic photosynthesis if no oxygen is available. As long as oxygen is present Rhodobacter species produce ATP by aerobic respiration. The molecular mechanisms underlying the rapid adaptation to changes in oxygen concentration have been extensively studied in the past (reviewed by Gregor \& Klug, 1999, 2002; ZeilstraRyalls \& Kaplan, 2004). In its natural environment Rhodobacter occasionally needs to tolerate very high oxygen concentrations which are produced by micro-organisms performing oxygenic photosynthesis. While some previous studies have addressed the role of superoxide dismutase and thioredoxins in defence against oxidative stress in Rhodobacter (Cortez et al., 1998; Pasternak et al., 1999; Li et al., 2003a, b), little is known about the role of catalases and their regulation. In this study we have addressed the ability of two Rhodobacter species to detoxify $\mathrm{H}_{2} \mathrm{O}_{2}$ and have studied the expression of catalase genes in order to understand better how Rhodobacter can deal with high oxygen concentrations in its environment.

\section{METHODS}

Bacterial strains, plasmids and growth conditions. All strains and plasmids used in this study are listed in Table 1.

E. coli cultures were grown in Luria-Bertani (LB) medium at $37^{\circ} \mathrm{C}$ with continuous shaking at 180 r.p.m. Rhodobacter cultures were cultivated at $32{ }^{\circ} \mathrm{C}$ with continuous shaking at 140 r.p.m. in a malate minimal salt medium (Drews, 1983). For aerobic growth, $20 \mathrm{ml}$ of culture were incubated in $100 \mathrm{ml}$ baffled Erlenmeyer flasks (about $7 \cdot 7 \mathrm{mg} \mathrm{l}^{-1}$ dissolved oxygen). For semi-aerobic incubation, $40 \mathrm{ml}$ of culture were shaken in $50 \mathrm{ml}$ Erlenmeyer flasks (about $0.85 \mathrm{mg} \mathrm{l}^{-1}$ dissolved oxygen). Ampicillin $\left(200 \mu \mathrm{g} \mathrm{ml}^{-1}\right)$, spectinomycin $(10 \mu \mathrm{g}$ $\left.\mathrm{ml}^{-1}\right)$ and tetracycline $\left(20 \mu \mathrm{g} \mathrm{ml}^{-1}\right)$ were added to the medium as needed.

Construction of oxy $R$ deletion mutants of $R$. capsulatus and R. sphaeroides. $R$. capsulatus strain SBoxyR:: $\Omega$ Sp and $R$. sphaeroides strain 2.4.10xyR:: $\Omega \mathrm{Sp}$ were generated by transferring the 
Table 1. Bacterial strains and plasmids used in this study

\begin{tabular}{|c|c|c|}
\hline Strain/plasmid & Description* & Source/reference \\
\hline \multicolumn{3}{|l|}{ Strain } \\
\hline \multicolumn{3}{|l|}{ E. coli } \\
\hline M15 (pREP4) & Host strain for protein over-expression & Qiagen \\
\hline SM10 & recA thi thr leu; chromosomal RP4-2 (Tc:: Mu) & Simon et al. (1983) \\
\hline JM109 & recA1 supE44 endA1 hsdR17 gyrA96 relA1 thi (lac-proAB) & New England Biolabs \\
\hline \multicolumn{3}{|l|}{ Rhodobacter } \\
\hline R. sphaeroides 2.4 .1 & Wild-type & van Neil (1941) \\
\hline R. capsulatus SB1003 & Wild-type & Yen \& Marrs (1976) \\
\hline 2.4.1oxyR & 2.4.1 oxyR:: $\Omega S \mathrm{p}^{\mathrm{r}}$ & This study \\
\hline SBoxyR & SB1003 oxyR:: $\Omega S \mathrm{p}^{\mathrm{r}}$ & This study \\
\hline 2.4.1oxyR(p2.4.1oxyR) & 2.4.1 oxyR harbouring $\mathrm{p} 2.4 .10 x y R$ & This study \\
\hline $\mathrm{SB} o x y R(\mathrm{pSB} o x y R)$ & SBoxyR harbouring pSBoxyR & This study \\
\hline \multicolumn{3}{|l|}{ Plasmid } \\
\hline pPHU281 & $\mathrm{Tc}^{\mathrm{r}}, \operatorname{lac} Z^{\prime} \operatorname{mob}(\mathrm{RP} 4)$ & Hübner et al. (1991) \\
\hline $\mathrm{pHP} 45 \Omega$ & $\mathrm{Ap}^{\mathrm{r}}, \mathrm{Sp}^{\mathrm{r}}$, source of $\Omega S \mathrm{p}^{\mathrm{r}}$ cassette & Prentki et al. (1991) \\
\hline pQE32 & His-tag vector for cloning $o x y R$ gene & Qiagen \\
\hline pRK415 & $\mathrm{Tc}^{\mathrm{r}}$ & Keen et al. (1988) \\
\hline TkatGup & $\begin{array}{l}0 \cdot 36 \mathrm{~kb} \text { BamHI-StuI DNA fragment containing SB1003 katG } \\
\text { promoter sequence cloned into T-vector (Promega), } \text { Ap }^{\mathrm{r}}\end{array}$ & This study \\
\hline pQEoxyR & $\begin{array}{l}0.95 \mathrm{~kb} \text { BamHI-KpnI DNA fragment containing the SB1003 oxyR } \\
\text { gene cloned into pQE32 (Qiagen) for } \text { oxyR over-expression, } \mathrm{Ap}^{\mathrm{r}}\end{array}$ & This study \\
\hline pPHU $\Delta$ SBoxyR & $\begin{array}{l}0 \cdot 75 \mathrm{~kb} \text { fragment containing the upstream and downstream regions } \\
\text { of the } R \text {. capsulatus oxyR gene cloned into pPHU } 281\end{array}$ & This study \\
\hline $\mathrm{pPHU} \Delta \mathrm{SB} \operatorname{oxyR}:: \Omega \mathrm{Sp}$ & $2 \cdot 0 \mathrm{~kb}$ omega spectinomycin cassette cloned into pPHU $\Delta \mathrm{SB}$ oxyR & This study \\
\hline pPHU $\Delta 2.4 .1$ oxyR & $\begin{array}{l}0.75 \mathrm{~kb} \text { fragment containing the upstream and downstream regions } \\
\text { of the } R \text {. sphaeroides oxyR gene cloned into pPHU } 281\end{array}$ & This study \\
\hline pPHU $\Delta 2.4 .1$ oxyR:: $\Omega S p$ & $2 \cdot 0 \mathrm{~kb}$ omega spectinomycin cassette cloned into pPHU $\Delta 2.4 .1$ oxyR & This study \\
\hline $\mathrm{p} 2.4 .10 x y R$ & $\begin{array}{l}2 \cdot 1 \mathrm{~kb} \text { fragment containing the upstream region of } \operatorname{oxy} R \text { and the } \\
\operatorname{oxy} R \text { gene of } 2.4 .1 \text { cloned into pRK415 }\end{array}$ & This study \\
\hline pSBoxyR & $\begin{array}{l}1.4 \mathrm{~kb} \text { fragment containing the upstream region of } \operatorname{oxyR} \text { and the } \\
\text { oxyR gene of } \mathrm{SB} 1003 \text { cloned into pRK415 }\end{array}$ & This study \\
\hline
\end{tabular}

${ }^{\star} \mathrm{Sp}^{\mathrm{r}}$, Spectinomycin-resistant; $\mathrm{Tc}^{\mathrm{r}}$, tetracycline-resistant; $\mathrm{Ap}{ }^{\mathrm{r}}$, ampicillin-resistant.

suicide plasmids pPHUSB $\Delta$ oxyR:: $\Omega$ Sp into $R$. capsulatus SB1003 and pPHU2.4.1 $\triangle$ oxyR:: $\Omega$ Sp in $R$. sphaeroides 2.4.1, respectively, and screening for insertion of the omega $(\Omega)$-spectinomycin cassette into the chromosome by homologous recombination. Briefly, parts of the oxyR genes of $R$. capsulatus $\mathrm{SB1003}$ or $R$. sphaeroides 2.4.1, together with upstream and downstream sequences were amplified by PCR using oligonucleotides SBoxyupEco (5'-GTGTTCGAATTCCCCGCC-3'), SBoxy315Bam (5'-GAAGATAGGATCCAATCGTCG-3') and SBoxy500Bam (5'-GAAGATAGGATCCAATCGTCG-3'), SBoxydownPst (5'-CAGGCGCTGCAGAGGGCG-3') for SB1003 and 2.4.10xyupEco (5'-CGAATTCTGGTTGTCGGCGATC-3'), 2.4.10xy290Bam (5'-GGGATCCCGCCCAGATTGAC-3'), 2.4.10xy600Bam (5'-CGGATCCGCTGCGGCGGTGGCGC-3') and 2.4.1oxydownPst $\quad\left(5^{\prime}\right.$-CCTGCAGGACGGCCGCGTGGA-3') for 2.4.1.

The amplified PCR fragments were cloned into the EcoRI-BamHI and BamHI-PstI sites of the suicide plasmid pPHU281, respectively, generating plasmids pPHUSB $\Delta o x y$ and pPHU2.4.1 $\Delta o x y R$. A $2 \cdot 0 \mathrm{~kb}$ BamHI fragment containing the $\Omega$-spectinomycin cassette from $\mathrm{pHP} 45 \Omega$ was inserted into the BamHI site of pPHUSB $\Delta$ oxy and pPHU2.4.1 $\triangle$ oxyR to generate pPHUSB $\triangle o x y R:: \Omega S p$ and

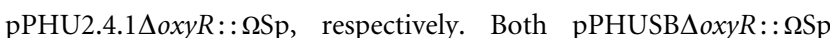
and pPHU2.4.1 $\Delta$ oxyR::SSp were transferred into E. coli strain SM10, and mobilized from SM10(pPHUSB $\Delta o x y R:: \Omega S p)$ or SM10(pPHU2.4.1 $\operatorname{oxy} R:: \Omega \mathrm{Sp}$ ), into either $R$. capsulatus SB1003 or $R$. sphaeroides 2.4 .1 wild-type strain by diparental conjugation. Conjugants were selected on malate minimal salt agar plates containing $10 \mu \mathrm{g}$ spectinomycin $\mathrm{ml}^{-1}$. Southern blot analysis of chromosomal DNA was carried out to confirm the double crossover event of the $\Omega$-spectinomycin cassette into the Rhodobacter chromosome. By insertion of the $\Omega$-spectinomycin cassette, $181 \mathrm{bp}$ of the $915 \mathrm{bp}$ $R$. capsulatus oxyR gene and 247 bp of the 926 bp R. sphaeroides oxyR gene, respectively, were deleted.

Complementation of the oxyR deletion mutants of $\boldsymbol{R}$. capsulatus and $\boldsymbol{R}$. sphaeroides. For complementation of the $\operatorname{oxy} R$ deletion mutant of $R$. capsulatus, a $1.4 \mathrm{~kb}$ PCR fragment containing the entire $\operatorname{oxy} R$ gene along with approximately $450 \mathrm{bp}$ of the upstream sequence was amplified using the oligonucleotides SBoxyRup450Eco (5'-GACGTTGTCGGGCCAGGAATTCAGC-3') and SBoxydownKpn (5'-GGGGTACCTGGCCTCGGTCAGATTTG$\left.3^{\prime}\right)$. Following digestion with EcoRI and $K p n I$, the PCR fragment was cloned into the corresponding sites of pRK415, resulting in 
plasmid pSBoxyR. For complementation of the $\operatorname{oxyR}$ deletion mutant of $R$. sphaeroides, a $1.2 \mathrm{~kb}$ PCR fragment containing the entire $\operatorname{oxy} R$ gene along with $100 \mathrm{bp}$ of the upstream sequence was amplified using the oligonucleotides 2.4.10xyupEco (5'-CGAATTCTGGTTGTCGGCGATC- $3^{\prime}$ ) and 2.4.1oxydownPst (5'-CCTGCAGGACGGCCGCGTGGA-3'). After digestion with EcoRI and PstI, the PCR fragment was cloned into the corresponding sites of pRK415 resulting in plasmid p2.4.1oxyR. To complement the oxyR deletion in SB1003 and 2.4.1, respectively, plasmids pSBoxyR and p2.4.1 oxyR were transferred into E. coli strain SM10 and conjugated into the $\mathrm{SB} \operatorname{oxy} R$ or 2.4.1 oxyR strains by diparental conjugation.

Enzyme assays. Rhodobacter cells were disrupted by brief sonication, and crude extract was used for enzyme assays. Protein concentration was determined according to Bradford (1976). For total catalase measurement, $30-300 \mu \mathrm{g}$ of total protein were diluted to $1 \mathrm{ml}$ with water. $\mathrm{H}_{2} \mathrm{O}_{2}\left(0.5 \mathrm{ml}\right.$ of $59 \mathrm{mM} \mathrm{H}_{2} \mathrm{O}_{2}$ freshly diluted in $50 \mathrm{mM}$ potassium phosphate buffer, $\mathrm{pH} 7 \cdot 0$ ) was added, and the absorbance of the samples at $240 \mathrm{~nm}$ was measured every $10 \mathrm{~s}$ for $1 \mathrm{~min}$. The initial linear rates were used to calculate the activities. Specific activity of catalase $\left(\mu \mathrm{M} \mathrm{H}_{2} \mathrm{O}_{2}\right.$ decomposed per minute per milligram of total protein) was calculated using an extinction coefficient of $43 \cdot 6 \mathrm{M}^{-1} \mathrm{~cm}^{-1}$ (Hochman \& Shemesh, 1987).

For analysis of $\mathrm{H}_{2} \mathrm{O}_{2}$ detoxification, cells were grown exponentially to an $\mathrm{OD}_{660}$ of 0.5 and $\mathrm{H}_{2} \mathrm{O}_{2}$ was added to the desired final concentration. Aliquots were drawn at various time points, and the amount of $\mathrm{H}_{2} \mathrm{O}_{2}$ was determined by oxidation of $\mathrm{Fe}^{2+}$ in the presence of xylenol orange and measuring the absorbance at $560 \mathrm{~nm}$. The absorbance of standard concentrations of $\mathrm{H}_{2} \mathrm{O}_{2}$ served to quantify the amount of $\mathrm{H}_{2} \mathrm{O}_{2}$ for each experiment. As previously described by Perelman et al. (2003), the ability to decompose $\mathrm{H}_{2} \mathrm{O}_{2}$ is strongly dependent on cell density. Therefore, all of the analyses presented in this study were performed at a fixed cell density.

Measurement of resistance to $\mathbf{H}_{2} \mathbf{O}_{2}$. Exponentially grown cultures of Rhodobacter strains $(0.2 \mathrm{ml})$ were diluted into $2 \mathrm{ml}$ of pre-warmed top agar $(0 \cdot 7 \%$ agar) and layered onto minimal malate agar plates. Filter paper disks were placed on the surface of the agar, and $5 \mu \mathrm{l}$ of different concentrations $(0 \cdot 001-0 \cdot 2 \mathrm{M}) \mathrm{H}_{2} \mathrm{O}_{2}$ were applied on the filter disk. Zones of inhibition were measured after overnight incubation at $32{ }^{\circ} \mathrm{C}$.

RNA extraction and quantitative real-time RT-PCR analysis. Rhodobacter strains in exponential phase $\left(\mathrm{OD}_{660}=0 \cdot 5\right)$, grown under semi-aerobic conditions, were treated with $\mathrm{H}_{2} \mathrm{O}_{2}$ ( $1 \mathrm{mM}$ final concentration) and at certain time-points cells were collected into centrifugation bottles and pelleted by centrifugation. Total RNA was isolated by the hot phenol method, quantified by spectrophotometric analysis (absorbance at $260 \mathrm{~nm}$ ), and $60 \mathrm{ng}$ of total RNA were used for quantitative real-time PCR.

The following primers were designed for gene amplification, katE: katE-A (5'-CTATCCGCTGATCGAGGT-3') and katE-B (5' -GTCGGCATAGGAGAAGAC-3'); katC: katC-A (5'-GGATGCGGCGATGCTAGCCGCCAAC-3') and katC-B (5'-GAGGGTTCCCGCCCAGCGTCGCC-3'); katG: katG-A (5'-GCCTCGGTCGCCGATGTGAT-3') and katG-B (5'-CACCGGCTCCAGCACGTCAA-3'); rpoZ genes: 2.4.1rpoZ-A (5'-TTCGAGCTGGTGATGCT-3') and 2.4.1rpoZ-B (5'-ACTCGATCTGGGTCTGG-3'); SBropZ-A (5'-GATGATCTGCGCGAGCGTCT-3') and SBrpoZ-B (5'-CCTTGCGCGTCCATCAATGC-3').

The rpoZ gene (encoding the $\omega$-subunit of RNA-polymerase) of $R$. capsulatus and R. sphaeroides, respectively, was used to normalize expression values for all other genes. The One-Step RT-PCR kit (Qiagen) was used for reverse-transcription-PCR following the manufacturer's instruction, except that a total volume of $15 \mu \mathrm{l}$ was used. SYBR Green was used to monitor amplification and to quantify the amount of PCR products using the Rotor-Gene 3000 real-time PCR cycler (LTF). Relative expression of kat and rpoZ mRNA were calculated after the method of Pfaffl (2001).

Expression and isolation of the $R$. capsulatus OxyR protein. Oligonucleotides SBoxystartBam (5'-CCCCGGATCCTCTCGATGAAACAGC-3') and SBoxydownKpn (5'-GGGGTACCTGGCCTCGGTCAGATTTG-3'), which hybridize to the $5^{\prime}$ and $3^{\prime}$ regions of the $\operatorname{oxy} R$ gene, respectively, were used to amplify the $\operatorname{oxy} R$ coding region. The $950 \mathrm{bp}$ PCR product was digested with BamHI and $K p n \mathrm{I}$ and ligated into $\mathrm{pQE} 32$ to generate $\mathrm{pQE}$ oxyR, which was transformed into E. coli JM109. The correct construct as confirmed by sequencing (using a Genetic Analyser 310 sequencer; ABI) was transformed into E. coli M15(pREP4) for overexpression of His-tagged OxyR. For this purpose M15(pREP4 pQEoxyR) was grown in $500 \mathrm{ml}$ of $\mathrm{LB}$ medium to an $\mathrm{OD}_{600}$ of $0 \cdot 7-0 \cdot 8$ and induced with $1 \mathrm{mM}$ IPTG for $4-5 \mathrm{~h}$ at $32^{\circ} \mathrm{C}$. Following harvest, cells were resuspended in lysis buffer $(50 \mathrm{mM}$ Tris, $\mathrm{pH} 7 \cdot 5 ; 250 \mathrm{mM} \mathrm{NaCl} ; 3 \mathrm{mM}$ imidazole; $1 \mu \mathrm{g}$ lysozyme $\mu \mathrm{l}^{-1}$ and $0 \cdot 1 \mathrm{mM}$ PMSF) and disrupted by a brief sonication. The lysate was centrifuged at 12000 r.p.m. for $20 \mathrm{~min}$ at $4{ }^{\circ} \mathrm{C}$. The supernatant was loaded onto Ni-NTA agarose and incubated at $4{ }^{\circ} \mathrm{C}$ for $4-5 \mathrm{~h}$. Proteins were washed with washing buffer $(0.05 \mathrm{M}$ Tris, $\mathrm{pH} 7.5$ and $0.25 \mathrm{M} \mathrm{NaCl})$ containing 20-50 mM imidazole and eluted with imidazole at a concentration between 80 and $100 \mathrm{mM}$. Aliquots of these fractions were analysed on SDS $15 \%$ polyacrylamide gels, using the buffer system of Laemmli (1970). Fractions containing purified OxyR protein were pooled by using Centricon-10 columns (Amicon) and washed in $\mathrm{Z}$ buffer (50 mM HEPES, pH 8.0; $0.5 \mathrm{mM}$ EDTA, pH 8.0; $10 \mathrm{mM}$ $\mathrm{MgCl}_{2}$ and $300 \mathrm{mM} \mathrm{KCl}$ ).

Gel chromatography (FPLC). The purified OxyR protein in a $2 \mathrm{ml}$ volume was applied to a Superdex-200 HR 16/60 gel filtration column (Pharmacia Biotech) equilibrated with $\mathrm{Z}$ buffer. For reducing conditions $200 \mathrm{mM}$ DTT was added to the $Z$ buffer. The protein was eluted with $\mathrm{Z}$ buffer and aliquots of the column fractions were analysed by SDS $10 \%$ PAGE using the buffer system of Laemmli (1970).

Determination of OxyR redox status by using AMS. For in vitro modification of free thiol groups, 4-acetamido- $4^{\prime}$-maleimidylstibene-2' $2^{\prime}$ '-disulfonic acid (AMS; Molecular Probes) was used. The addition of AMS leads to the alkylation of free thiol groups, present in the reduced but not in the oxidized OxyR. The addition of the high-molecular-mass AMS moiety to the reduced but not to the oxidized protein allows separation of the two forms by gel electrophoresis. The purified OxyR protein was first treated with freshly prepared $\mathrm{H}_{2} \mathrm{O}_{2}(1 \mathrm{mM})$ or DTT $(200 \mathrm{mM})$ at room temperature for $30 \mathrm{~min}$. The protein was then mixed with $10 \%$ trichloroacetic acid (TCA). Precipitated protein was collected by centrifugation (10000 r.p.m., $10 \mathrm{~min}$ ). After complete removal of the supernatant, the pellet was dissolved in a buffer containing $0 \cdot 1 \%$ SDS; $50 \mathrm{mM}$ Tris/ $\mathrm{HCl}, \mathrm{pH} 8 \cdot 0$ and $15 \mathrm{mM}$ AMS (apart from the non-AMS-modified sample which was dissolved in the same buffer without AMS), and incubated for $2 \mathrm{~h}$ at $37^{\circ} \mathrm{C}$. The samples were loaded on SDS $10 \%$ PAGE and visualized by silver staining.

Gel mobility-shift assay. Binding of the OxyR protein to the $k a t G$ and katE upstream region, respectively, was determined by gel mobility-shift assay. For this, a DNA fragment containing the $k a t G$ or the katE promoter region was generated by PCR. The following oligonucleotides were used to generate the PCR fragments. katG: katGupBspEI (5'-CGTCCGGACCCGCGGCACCATC$\left.3^{\prime}\right)$ and katGStuI (5'-AGGCCTTCATCGCGCCATGCAT-3'); katE: katEupEcoRI (5'-GTAGAATTCCTGCCGCAG-3') and katEPstI (5'GTCTGCAGTCGGCGCGCCGGCCGT- $3^{\prime}$ ). The PCR fragments with a length of $350 \mathrm{bp}$ were cloned into T-vector (Promega), and 
isolated from the vector by using enzymes BspEI/StuI and EcoRI/ PstI, respectively. The restricted DNA fragments were then radioactively labelled in a fill-in reaction with $\left[\alpha_{-}{ }^{32} \mathrm{P}\right] \mathrm{dCTP}$ using the Klenow fragment.

Binding reactions were carried out in a final volume of $20 \mu \mathrm{l}$ and contained an appropriate amount of protein, $\left[\alpha-{ }^{32} \mathrm{P}\right] \mathrm{CTP}$-labelled DNA probe, and binding buffer $(10 \mathrm{mM}$ Tris/ $\mathrm{HCl}, \mathrm{pH} 8 \cdot 0 ; 50 \mathrm{mM} \mathrm{NaCl}$; $1 \mathrm{mM}$ DTT; $1 \mathrm{mM}$ EDTA and 5\% glycerol). Since purified OxyR protein is predominantly in the oxidized form, we added $200 \mathrm{mM}$ DTT to the binding reaction to reduce OxyR. Binding incubations were carried out for $30 \mathrm{~min}$ at room temperature $\left(25^{\circ} \mathrm{C}\right)$ before the samples were loaded onto a $4 \%$ polyacrylamide gel in $0.5 \times$ Tris Borate EDTA (TBE) buffer and run at $130 \mathrm{~V}$ for $2 \mathrm{~h}$.

DNasel footprinting assay. A BamHI-StuI DNA fragment containing the kat $G$ promoter region was $5^{\prime}$-end labelled at the BamHI site as follows. Plasmid TkatGup (Table 1) was linearized with Bam HI, dephosphorylated using alkaline phosphatase (NEB) and labelled with polynucleotide kinase (NEB) and $\left[\gamma^{32} \mathrm{P}\right] \mathrm{ATP}$. The DNA was then digested with StuI and the $361 \mathrm{bp} \mathrm{BamHI-StuI} \mathrm{frag-}$ ment was purified from a $6 \%$ non-denaturing polyacrylamide gel. The end-labelled DNA fragment (approx. 10000 c.p.m.) was incubated with different amounts of purified OxyR protein, using the same reaction conditions as described for the gel mobility-shift assay. After $30 \mathrm{~min}$ of incubation at room temperature, $5 \mu \mathrm{l}$ of a buffer containing $0.01 \mathrm{M} \mathrm{CaCl}_{2}$ and $0.01 \mathrm{M} \mathrm{MgCl}$ were added. DNaseI $\left(1 \mu \mathrm{l}, 0 \cdot 1 \mathrm{U}^{-1}\right.$; Promega) was then added for $2 \mathrm{~min}$ at room temperature. The reaction was stopped by adding $250 \mathrm{mM}$ EDTA. After phenol/chloroform extraction, the samples were dissolved in formamide dye and loaded onto a $6 \%$ sequencing gel. The DNA fragment containing the kat $G$ promoter region was sequenced with the primer SBkatG300seq (5'-GCACCATCGCCGCGCCCAG$3^{\prime}$ ) by the dideoxy chain-termination method (Sanger et al., 1977) using the T7 sequencing kit from USB.

\section{RESULTS}

\section{R. sphaeroides 2.4 .1 is more resistant to $\mathrm{H}_{2} \mathrm{O}_{2}$ and shows faster $\mathrm{H}_{2} \mathrm{O}_{2}$ detoxification than R. capsulatus SB1003}

In order to compare the sensitivity of the two related Rhodobacter strains to $\mathrm{H}_{2} \mathrm{O}_{2}$ we performed inhibition zone assays. Fig. 1(a) shows the mean sizes of inhibition zones at the different concentrations of $\mathrm{H}_{2} \mathrm{O}_{2}$ which had been applied to the filters. R. sphaeroides 2.4 .1 is clearly more resistant to $\mathrm{H}_{2} \mathrm{O}_{2}$ at lower concentrations and can tolerate higher concentrations of the agent. While $R$. capsulatus SB1003 showed significant growth inhibition when $12.5 \mathrm{mM}$ $\mathrm{H}_{2} \mathrm{O}_{2}$ was spotted on the filter, $R$. sphaeroides 2.4 .1 only showed inhibition when $25 \mathrm{mM} \mathrm{H}_{2} \mathrm{O}_{2}$ was applied. We also monitored the detoxification of $\mathrm{H}_{2} \mathrm{O}_{2}$ added to exponentially growing cultures of $R$. sphaeroides or $R$. capsulatus (Fig. 1b). Both strains showed faster removal of $\mathrm{H}_{2} \mathrm{O}_{2}$ when grown aerobically compared to semi-aerobic growth. While the two Rhodobacter strains showed identical rates of $\mathrm{H}_{2} \mathrm{O}_{2}$ detoxification under aerobic conditions, semiaerobically grown $R$. sphaeroides cultures were clearly more efficient than semi-aerobic $R$. capsulatus cultures. Similar results were obtained in the measurement of the basal catalase activity (Table 2). While an activity of about $200 \mu \mathrm{M}$ decomposed $\mathrm{H}_{2} \mathrm{O}_{2} \min ^{-1}$ (mg total protein) ${ }^{-1}$ was (a)

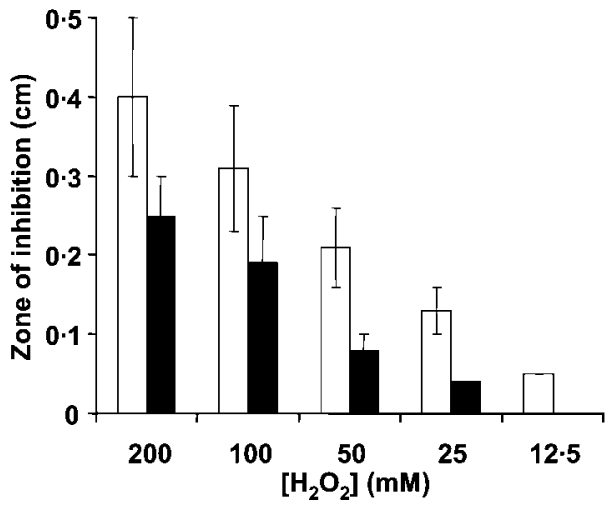

(b)

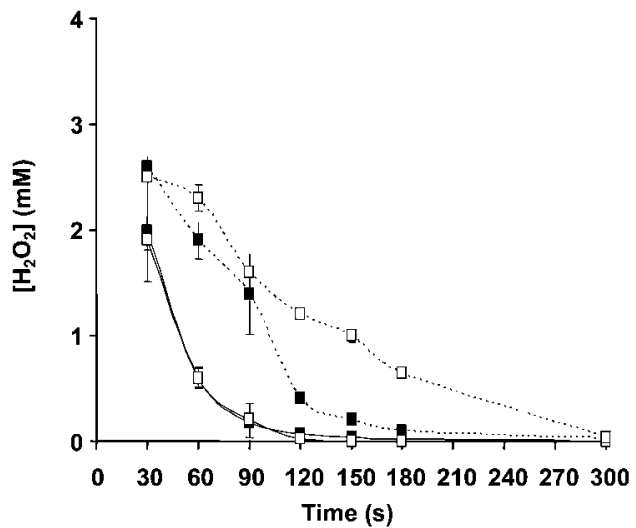

Fig. 1. Effect of $\mathrm{H}_{2} \mathrm{O}_{2}$ on wild-type strains of Rhodobacter. (a) Inhibition of growth of $\mathrm{SB} 1003$ (open bars) and 2.4.1 (filled bars) by $\mathrm{H}_{2} \mathrm{O}_{2}$. The values give the mean of five experiments with maximal deviation. (b) Time-course of $\mathrm{H}_{2} \mathrm{O}_{2}$ decomposition by aerobic (solid lines) or semi-aerobic (dashed lines) cultures of wild-type SB1003 $(\square)$ and 2.4.1 ( $\mathbf{\square}) \mathrm{H}_{2} \mathrm{O}_{2}(3.5 \mathrm{mM})$ was added to the cultures at time-point 0 . Each point represents the mean of four independent experiments. Error bars indicate maximal deviation.

determined for aerobically grown $R$. sphaeroides cells in exponential phase, an activity of only $40 \mu \mathrm{M}$ decomposed $\mathrm{H}_{2} \mathrm{O}_{2}$ min $^{-1}$ (mg total protein) ${ }^{-1}$ was determined for $R$. capsulatus cells grown under identical conditions. In contrast to that, semi-aerobically grown cells of R. sphaeroides showed a reduced catalase activity of about $130 \mu \mathrm{M}$ decomposed $\mathrm{H}_{2} \mathrm{O}_{2}$ min $^{-1}$ (mg total protein) ${ }^{-1}$ and cells of $R$. capsulatus an activity of $10 \mu \mathrm{M}$ decomposed $\mathrm{H}_{2} \mathrm{O}_{2}$ $\mathrm{min}^{-1}$ (mg total protein $)^{-1}$. These results indicate that $\mathrm{H}_{2} \mathrm{O}_{2}$-scavenging enzymes are present in higher amounts or show higher activity under aerobic growth conditions.

\section{The oxyR gene product is required for the $\mathrm{H}_{2} \mathrm{O}_{2}$-dependent response}

To study the involvement of the global stress regulator OxyR in the $\mathrm{H}_{2} \mathrm{O}_{2}$-dependent response, we constructed oxyR deletion mutants of both Rhodobacter strains (see Methods). The deletion of the $\operatorname{oxy} R$ gene resulted in higher sensitivities of the mutants after exposure to $\mathrm{H}_{2} \mathrm{O}_{2}$ in 
Table 2. Catalase activities of wild-type, oxyR mutant strains and oxyR-complemented strains of $R$. capsulatus and $R$. sphaeroides grown under aerobic or semi-aerobic conditions

\begin{tabular}{|lccc|}
\hline \multirow{2}{*}{ Strain } & \multicolumn{3}{c|}{ Catalase activity ${ }^{\star}$ exponential phase } \\
\cline { 2 - 4 } & Aerobic & Semi-aerobic & Semi-aerobic, $\mathbf{H}_{2} \mathbf{O}_{2}$-induced $\dagger$ \\
\hline 2.4 .1 & $209 \cdot 9 \pm 29 \cdot 8$ & $129 \cdot 9 \pm 33 \cdot 9$ & $251 \cdot 9 \pm 19 \cdot 4$ \\
2.4 .1 oxy $R$ & $43 \cdot 3 \pm 9 \cdot 6$ & $28 \cdot 0 \pm 10 \cdot 8$ & $38 \cdot 0 \pm 9 \cdot 6$ \\
2.4 .1 oxy $R(\mathrm{p} 2.4 .1$ oxy $R)$ & $119 \cdot 4 \pm 7 \cdot 8$ & $76 \pm 2 \cdot 5$ & $132 \cdot 3 \pm 30 \cdot 5$ \\
SB1003 & $40 \pm 11 \cdot 1$ & $10 \pm 4 \cdot 3$ & $42 \cdot 6 \pm 4$ \\
SBoxyR & $2 \cdot 2 \pm 1 \cdot 4$ & $0 \cdot 9 \pm 1 \cdot 3$ & $0 \cdot 7 \pm 0 \cdot 3$ \\
SBoxyR(pSBoxyR) & $27 \pm 2 \cdot 5$ & $8 \cdot 9 \pm 2 \cdot 2$ & $28 \pm 2$ \\
\hline
\end{tabular}

${ }^{\star}$ Catalase activities are given in $\mu \mathrm{M} \mathrm{H}_{2} \mathrm{O}_{2}$ decomposed $\min ^{-1}$ (mg total protein) ${ }^{-1}$ and are means of at least seven independent experiments, the error range represents standard deviation.

$\dagger$ Exponentially growing cells were treated with $250 \mu \mathrm{M} \mathrm{H}_{2} \mathrm{O}_{2}$ for $30 \mathrm{~min}$ prior to harvest.

comparison to the wild-types (Fig. 2a, b). The zones of growth inhibition were significantly larger for the $\operatorname{oxy} R$ mutants. The intact oxyR gene of 2.4.1 and SB1003, respectively, located on plasmids p2.4.1 oxyR and pSBoxyR could restore the $\operatorname{oxy} R$ deletion phenotype (Fig. 2a, b). Moreover, the basal level of total catalase activity was reduced in both $\operatorname{oxy} R$ mutant strains (fivefold decrease in 2.4.1 oxyR under aerobic and semi-aerobic conditions compared to the wild-type 2.4.1; 18- and 11-fold decrease, respectively, for $\mathrm{SB} o x y R$ under aerobic and semi-aerobic conditions compared to the wild-type SB1003) (Table 2). The increase in catalase activity after $\mathrm{H}_{2} \mathrm{O}_{2}$ treatment in the $\operatorname{oxyR}$ mutants was also reduced $(1 \cdot 3$-fold increase in 2.4.1 $\operatorname{oxy} R$ compared to $1 \cdot 9$-fold increase in 2.4.1 wild-type and $1 \cdot 3$-fold decrease in SBoxyR compared to $4 \cdot 3$-fold increase in SB1003 wild-type) (Table 2). The complemented $\operatorname{oxy} R$ mutant strains showed catalase activities that were clearly higher than that of both $\operatorname{oxyR}$ mutants, but the activities did not reach wild-type levels. In the complemented strains, the oxyR gene is present in 1-2 copies in trans, which may lead to altered expression compared to the chromosomally located wild-type gene. Both $\operatorname{oxy} R$ mutants exhibit kinetics of $\mathrm{H}_{2} \mathrm{O}_{2}$ removal which were clearly retarded when compared to the kinetics observed for the isogenic wild-type strains (Figs $2 \mathrm{c}$ and $1 \mathrm{~b}$ ). These data reveal an involvement of the $\operatorname{oxy} R$ gene product in the response to $\mathrm{H}_{2} \mathrm{O}_{2}$. Similar observations regarding the essential role of OxyR in the peroxide response have been made in other bacteria, such as E. coli, Haemophilus influenzae and Agrobacterium (González-Flecha \& Demple, 1997; Maciver \& Hansen, 1996; Nakjarung et al., 2003). The $R$. capsulatus mutant SBoxy $R$ was more severely affected in its ability to detoxify $\mathrm{H}_{2} \mathrm{O}_{2}$ than the $R$. sphaeroides oxyR mutant. While 2.4.1 oxyR was able to remove $3.5 \mathrm{mM}$ $\mathrm{H}_{2} \mathrm{O}_{2}$ from the medium within 5 min, SBoxyR was unable to remove this amount of $\mathrm{H}_{2} \mathrm{O}_{2}$ even after $5 \mathrm{~min}$. After addition of $3.5 \mathrm{mM} \mathrm{H}_{2} \mathrm{O}_{2}$ the growth of the R. capsulatus $\operatorname{oxy} R$ mutant was completely inhibited, while both wildtype strains, as well as the 2.4.10xyR mutant, showed growth inhibition for a period of $60 \mathrm{~min}$ after the addition of $\mathrm{H}_{2} \mathrm{O}_{2}$, but were able to grow after that time of adaptation (data not shown).

\section{$\mathrm{H}_{2} \mathrm{O}_{2}$-dependent katG expression in $R$. capsulatus and katE gene expression in R. sphaeroides are mediated by the OxyR protein}

Analysis of the completed genome of R. sphaeroides 2.4.1. (http://genome.ornl.gov/microbial/rsph) revealed the presence of two genes encoding catalases, RSP2779 and RSP2380. The RSP2779 gene product shows $45 \%$ identity to the E. coli hydroxyperoxidase (HP) II, which is encoded by the E. coli katE gene. The RSP2380 gene product shows $51 \%$ identity to the E. coli HPII protein but even higher identity to the katC gene products of Agrobacterium or Sinorhizobium. Like other KatC proteins it harbours a Cterminal protease domain. The almost completed genome of $R$. capsulatus SB1003 (data taken from: www.ergo-light. com/ERGO) contains only one gene with significant similarity to a catalase/peroxidase, katG. The kat $G$ gene product shows $53 \%$ identity to the E. coli HPI protein, which is encoded by the E. coli kat $G$ gene. We investigated the expression of these genes after addition of $\mathrm{H}_{2} \mathrm{O}_{2}$ by real-time RT-PCR. The expression of the katE gene of $R$. sphaeroides as well as expression of the katG gene of $R$. capsulatus were strongly induced after addition of $\mathrm{H}_{2} \mathrm{O}_{2}$ to exponentially growing cultures (Fig. 3a, b). High expression levels were already observed $1 \mathrm{~min}$ after the addition of $\mathrm{H}_{2} \mathrm{O}_{2}$. These data fit well with the fast kinetics of $\mathrm{H}_{2} \mathrm{O}_{2}$ detoxification observed for Rhodobacter cultures. Oxygen itself also exerted an effect on katE and $k a t G$ gene expression in R. sphaeroides and R. capsulatus, respectively (Fig. 4). The basal expression of both $k a t E$ and $k a t G$ were reduced about fivefold under semi-aerobic conditions. No change could be observed for the basal expression of $\mathrm{katC}$ when the cells were grown under aerobic or semi-aerobic conditions (Fig. 4).

The known ability of OxyR to positively regulate the expression of catalases in E. coli (Storz \& Zheng, 2000) prompted us to determine whether the OxyR protein of 
(a)

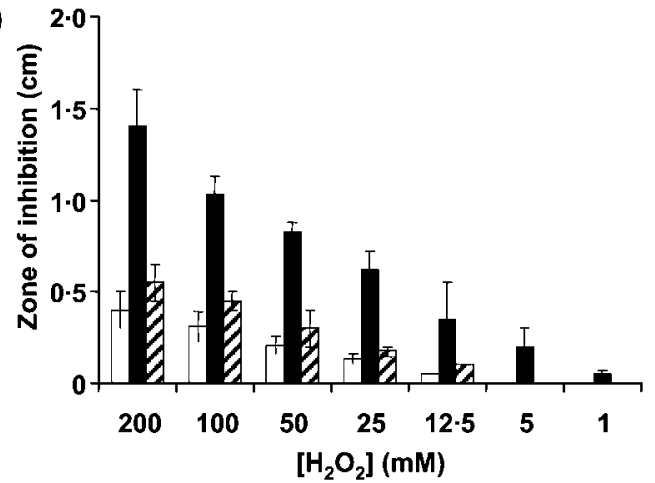

(b)

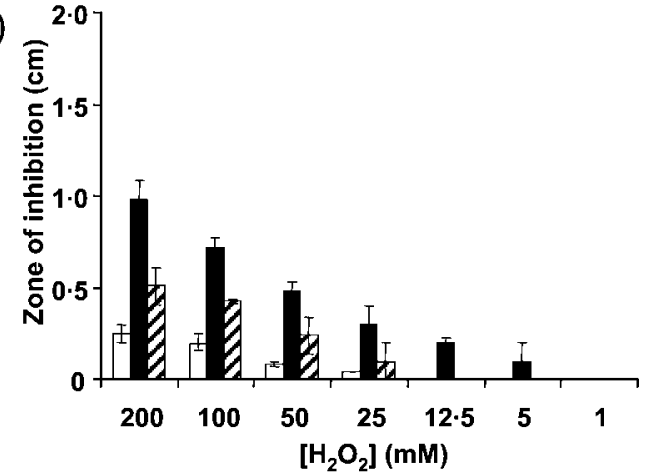

(c)

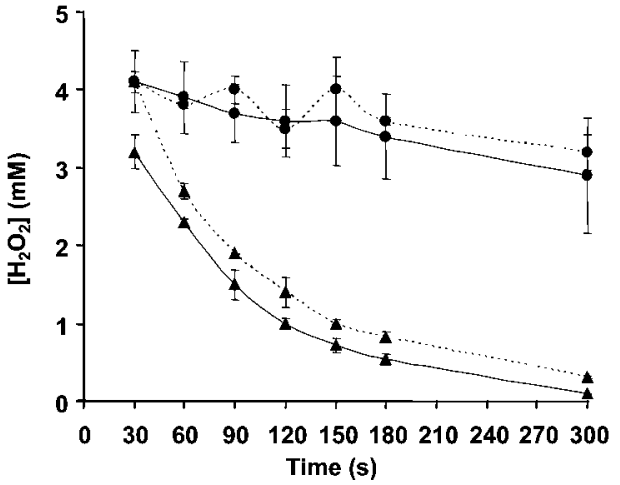

Fig. 2. Sensitivity of Rhodobacter oxyR mutants to $\mathrm{H}_{2} \mathrm{O}_{2}$. Growth inhibition by $\mathrm{H}_{2} \mathrm{O}_{2}$ of (a) $R$. capsulatus [open bars, wild-type SB1003; filled bars, SBoxyR; hatched bars, complemented mutant SBoxyR(pSBoxyR)] and (b) $R$. sphaeroides [open bars, wild-type 2.4.1; filled bars, 2.4.1 oxyR; hatched bars, complemented mutant 2.4.1 oxyR(p2.4.1 oxyR)]. The values give the mean of five experiments with maximal deviation. (c) Time-courses of $\mathrm{H}_{2} \mathrm{O}_{2}$ decomposition by aerobic (solid lines) or semi-aerobic (dashed lines) oxy $R$ mutant strains $\mathrm{SB}$ oxy $R$

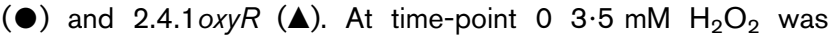
added to the cultures. Each point represents the mean of four independent experiments. Error bars indicate maximal deviation.

Rhodobacter is also involved in the regulation of the $\mathrm{H}_{2} \mathrm{O}_{2}$ dependent expression of catalases. The expression of $k a t E$ in $R$. sphaeroides and kat $G$ in $R$. capsulatus were both dependent on OxyR (Fig. 3a, b). Without the addition of $\mathrm{H}_{2} \mathrm{O}_{2}$ the expression levels in the oxyR mutant strains were similar to that of the parental wild-type strains. The (a)

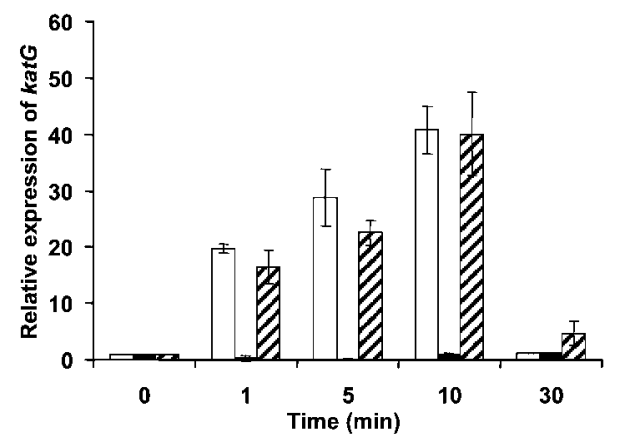

(b)

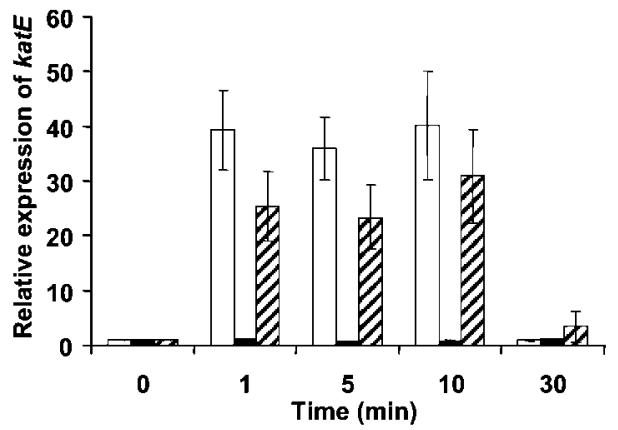

(c)

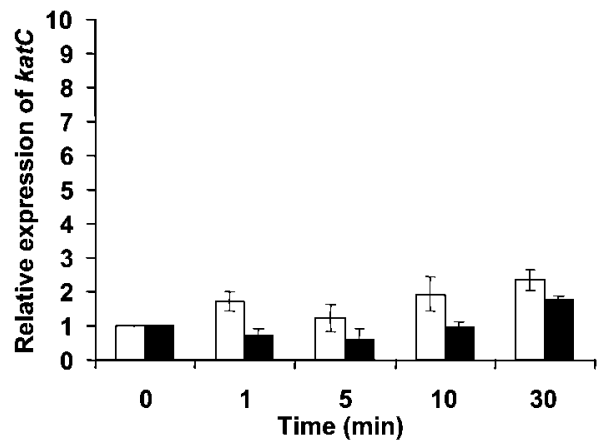

Fig. 3. Expression of kat genes in wild-type strains (open bars), oxyR mutant strains (filled bars) and complemented mutant strains (hatched bars). $\mathrm{H}_{2} \mathrm{O}_{2}$ was added to exponentially grown cultures to a final concentration of $1 \mathrm{mM}$, samples were taken at the indicated times. Total RNA was isolated and the level of kat expression was monitored by real-time RT-PCR analysis. (a) Expression of katG in $R$. capsulatus strains. (b) Expression of katE in $R$. sphaeroides strains. (c) Expression of katC in $R$. sphaeroides strains. Values represent the fold change of the kat gene expression compared to that of the control at time-point 0 . The data represent the mean of three independent experiments. Error bars indicate maximal deviation.

$\mathrm{H}_{2} \mathrm{O}_{2}$-inducibility of kat expression was regained by provision of a functional oxyR gene in trans (Fig. 3a, b). These data imply that the $o x y R$ gene product is important for regulation of the genes encoding $k a t E$ and $k a t G$, respectively, in Rhodobacter.

\section{Regulation of katC gene expression}

In contrast to the gene encoding katE of R. sphaeroides, the katC gene showed only a weak response when $\mathrm{H}_{2} \mathrm{O}_{2}$ was 


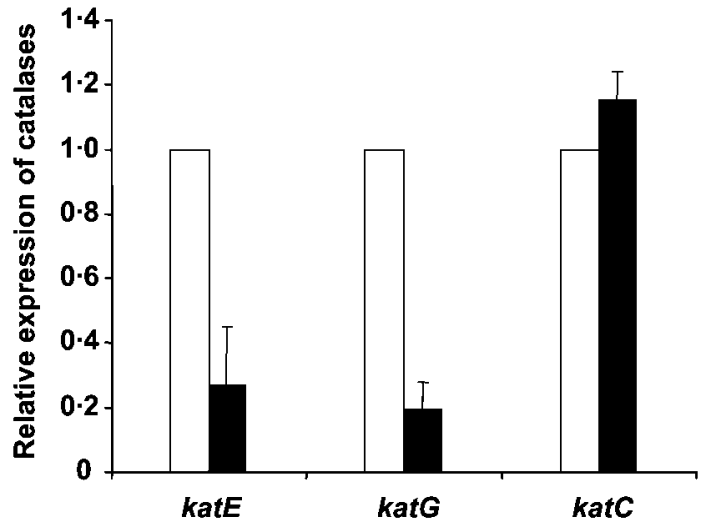

Fig. 4. Effect of oxygen tension on the expression of katC, $k a t E$ and katG. Cultures of strains SB1003 (wild-type $R$. capsulatus) and 2.4 .1 (wild-type $R$. sphaeroides) were grown under aerobic or semi-aerobic conditions to exponential phase. Total RNA was isolated and expression of kat genes (katG in $R$. capsulatus and katE and katC in $R$. sphaeroides) was analysed by real-time RT-PCR. Filled bars represent the fold change of the kat expression under semi-aerobic growth compared to the expression under aerobic conditions $(=1$; open bars). Values are means and maximal deviation of three independent experiments.

added to exponentially growing cultures of $R$. sphaeroides (Fig. 3c). The low $\mathrm{H}_{2} \mathrm{O}_{2}$-dependent induction of $\mathrm{katC}$ expression in $R$. sphaeroides was independent of OxyR (Fig. 3c). In contrast to the katE and kat $G$ basal expression levels, respectively, oxygen tension had no effect on the basal katC expression level (Fig. 4). To determine whether expression of the katC gene is induced in the stationary phase, as it was reported for Sinorhizobium meliloti (Sigaud et al., 1999), expression of the gene was measured by realtime RT-PCR during growth (Fig. 5a, b). An 11- to 38-fold increase in expression of $k a t C$ was observed when cells reached stationary phase, suggesting a function of the katC gene product in this growth stage. This finding is consistent with the results of Terzenbach \& Blaut (1998), who observed a twofold higher catalase activity in R. sphaeroides cells grown in stationary phase. Expression of katE did not increase after cells entered stationary phase (data not shown).

\section{Reduced and oxidized OxyR bind to the kat promoter region}

In E. coli, OxyR exerts its effect on gene expression by binding to promoter regions of target genes (Kullik et al., 1995). Some promoter regions bind only oxidized or reduced OxyR, other promoter regions can bind both forms, but only the oxidized form activates transcription (Kullik et al., 1995). To understand the regulation of kat genes by various forms of OxyR better, the DNA-binding ability of the Rhodobacter OxyR protein was tested. To do this, the oxyR gene of SB1003 was cloned and overexpressed (a)

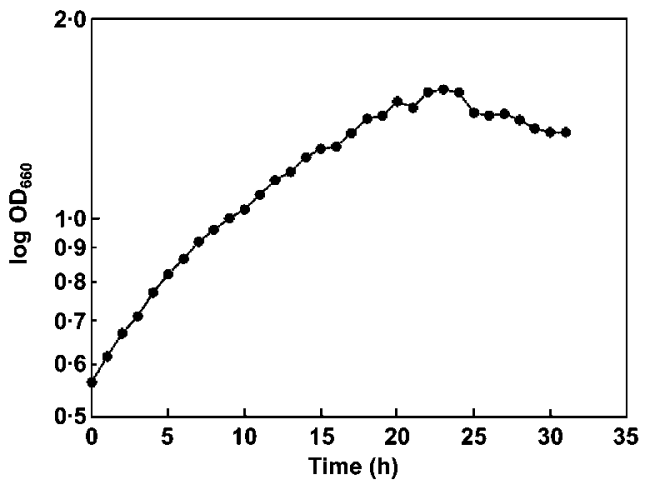

(b)

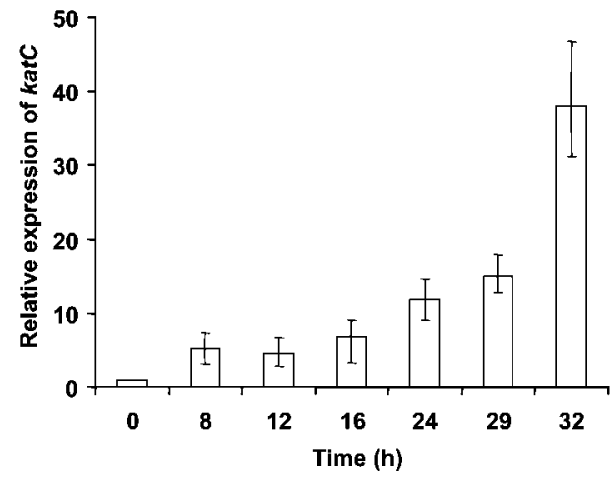

Fig. 5. Real-time RT-PCR analysis of katC expression during stationary phase. (a) Bacterial growth (expressed as log $\mathrm{OD}_{660}$ ) was monitored, samples were taken after 0, 8, 12, 16, 24, 29 and $32 \mathrm{~h}$ of growth. (b) Total RNA was isolated and the expression of $k a t C$ was measured by real-time RT-PCR. Values were calculated as fold change of the expression of katC compared to that of the control at time-point 0 . The data represent the mean of three independent experiments. Error bars indicate maximal deviation.

with an $\mathrm{N}$-terminal $\mathrm{His}_{6}$-tag in E. coli. The isolated protein showed specific binding to the $k a t G$ promoter region, no matter whether it was in its reduced or oxidized form. However, different types of DNA-protein complexes were formed by reduced and oxidized OxyR (Fig. 6a). At high concentrations, OxyR may bind to the kat $G$ promoter as an oligomer leading to the $\mathrm{C} 2$ band in the gel-shift experiment.

To test whether these different types of DNA-protein complexes are due to different sized DNA-protein complexes or rather to different conformation of the complexes, we performed gel filtration assays with purified protein. The purified protein was loaded on a Superdex-200 gel filtration column, and the fractions were analysed by SDSPAGE. The oxidized protein eluted predominantly in fractions that most likely correspond to a tetramer of the $32.2 \mathrm{kDa}$ OxyR protein $(128 \cdot 8 \mathrm{kDa})$ (Fig. $7 \mathrm{a})$. We also examined the size of the protein when the column was loaded and eluted in the presence of $200 \mathrm{mM}$ DTT. As shown by AMS modification, $200 \mathrm{mM}$ DTT reduced the 
(a)
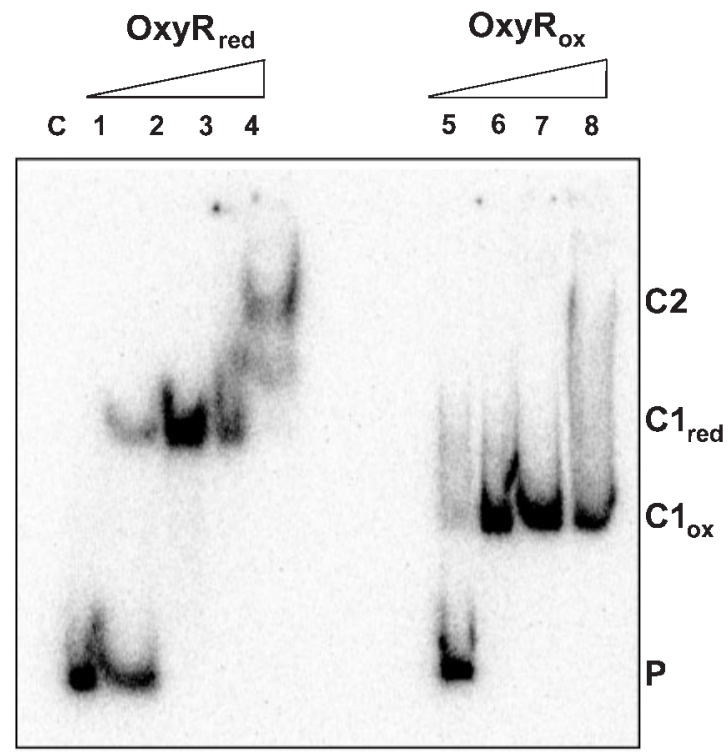

(b)

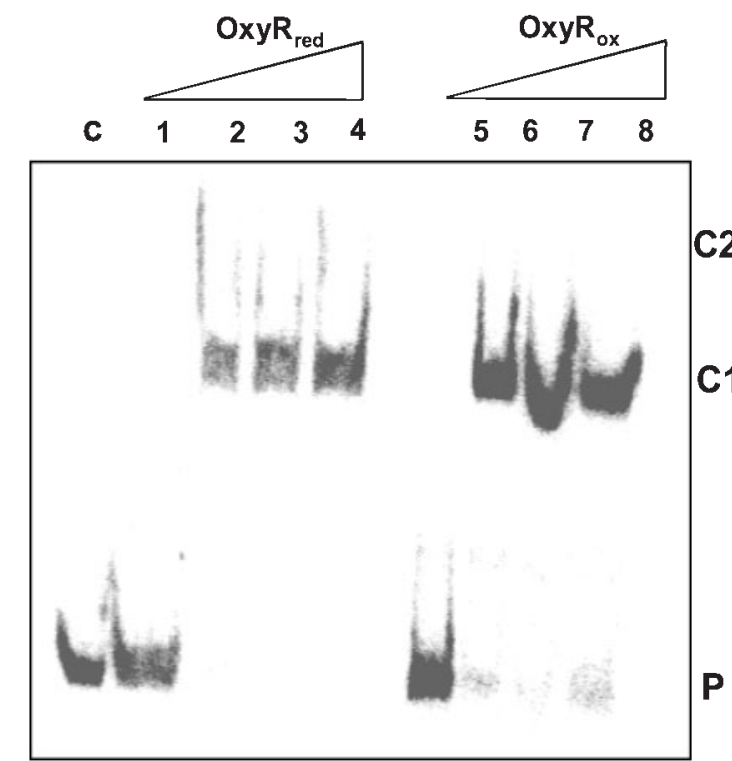

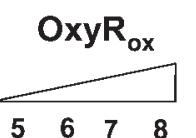

(c)

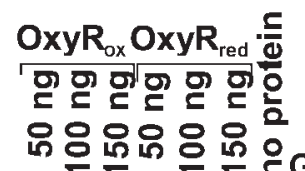

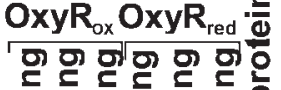

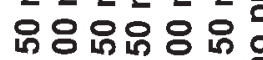

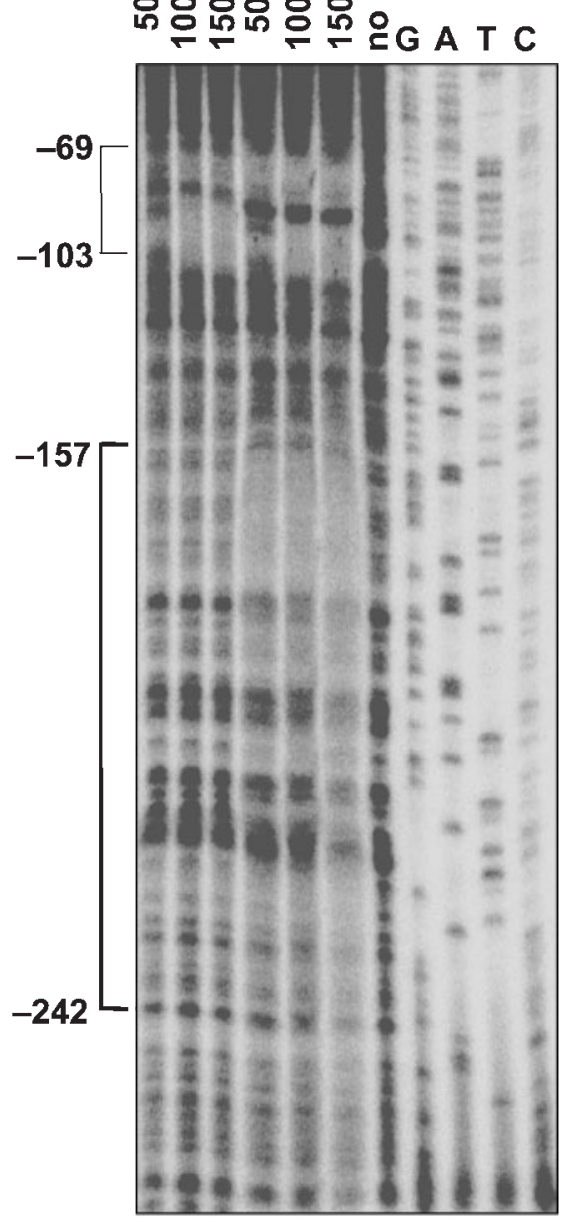

(d)

ACCCGCGGCA CCATCGCCGC GCCCAGCGCC GTCAGATGCA CCTGCCGCGG CCCGCGCtCG AaCAGCGCCG CGCCCATCGT CTCCTCCATC TCGCGGATCT GCACCGAAAG CGCGGGCTGC GAAATCGCGC AATCCTCGGC GGCGCGGCCG AAATGGCCCG TCCGCGCCAG CGCGTCGAAA TAGCGAAGCT GTTTCATCGA GAGGTTTATC

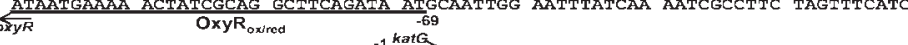
GCAACAGCAA CGACCCCAGC GGAGGACAAG ${ }^{-1}$ katG

Fig. 6. Binding of reduced and air-oxidized OxyR to the kat promoter region. To generate reduced conditions, $200 \mathrm{mM} \mathrm{DTT}$ was added to the binding reactions. Ox and red indicate oxidized and reduced OxyR, respectively. (a) Binding of OxyR to the katG promoter region. C1ox, complex 1 of DNA and oxidized OxyR; C1red, complex 1 of DNA and reduced OxyR; C2, complex 2. The following amounts of OxyR were added to the reaction: $10 \mathrm{ng}$ (lanes 1 and 5), $20 \mathrm{ng}$ (lanes 2 and 6), $50 \mathrm{ng}$ (lanes 3 and 7) and $100 \mathrm{ng}$ (lanes 4 and 8). (b) Binding of OxyR to the katE promoter region. C1, complex of DNA and oxidized or reduced OxyR; C2, complex 2. The following amounts of OxyR were added to the reaction: 10 ng (lanes 1 and 5), $20 \mathrm{ng}$ (lanes 2 and 6), $50 \mathrm{ng}$ (lanes 3 and 7), $100 \mathrm{ng}$ (lanes 4 and 8). P represents unbound probe, c represents the control without addition of OxyR. (c) DNasel footprinting assay with oxidized and reduced (in the presence of $200 \mathrm{mM}$ DTT) OxyR binding to the katG promoter region. The regions protected by OxyR are indicated by the brackets. The heavy brackets indicate the reduced extended footprint of OxyR, the light brackets indicate the shorter footprint of oxidized and reduced OxyR. The positions of the footprints are labelled with respect to the katG translational start site. (d) Sequence of the katG and $\operatorname{xy} R$ promoters. The starts of the $k a t G$ and the oxy $R$ coding sequences are indicated by arrows. Binding sites of oxidized and reduced OxyR are denoted by black bars. 
(a)

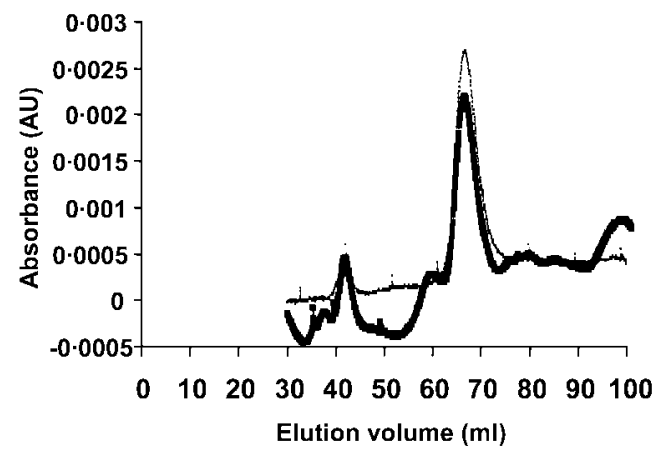

(b)

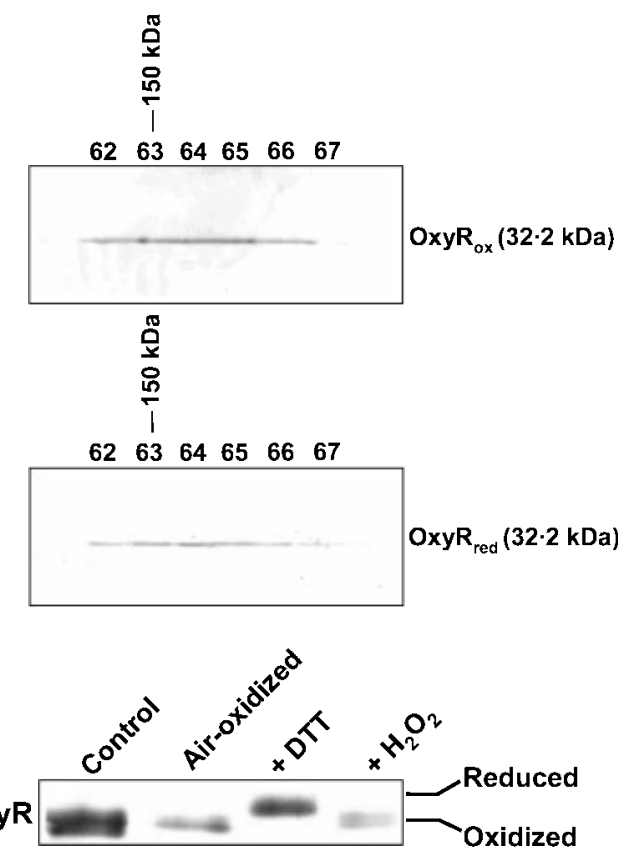

Fig. 7. (a) Analytical gel filtration profile of oxidized (thin line) and reduced (heavy line) OxyR protein. The purified OxyR protein was passed through a Superdex-200 HR 16/60 column equilibrated with $Z$ buffer. To generate reducing conditions, $200 \mathrm{mM}$ DTT was added to the $Z$ buffer. The flow rate was $1 \mathrm{ml} \mathrm{min}{ }^{-1}$, and the absorbance of the eluted protein was monitored at $280 \mathrm{~nm}$. (b) The elution fractions were analysed by SDS-PAGE. The elution position of the peak fraction for the standard protein immunoglobulin $\mathrm{G}(150 \mathrm{kDa})$ under oxidizing and reducing conditions is indicated. (c) Redox status of OxyR. OxyR protein (125 ng) was reduced or oxidized with $200 \mathrm{mM}$ DTT or $1 \mathrm{mM} \mathrm{H}_{2} \mathrm{O}_{2}$. Samples were mixed with $10 \% \mathrm{TCA}$ and then treated with AMS. Separation and visualization of OxyR was achieved by SDS-PAGE and silver staining. Control: OxyR without DTT, $\mathrm{H}_{2} \mathrm{O}_{2}$ and AMS treatment. The addition of AMS leads to the alkylation of free thiol groups, present in the reduced OxyR. The addition of the high molecular mass AMS moiety to the reduced but not to the oxidized protein allows separation of the two forms by gel electrophoresis.

OxyR protein completely (Fig. 7c). The elution profile observed under reducing conditions was identical to that in the absence of DTT (Fig. 7a, b). Protein eluted from the column in presence of DTT still resulted in band C1red in the gel shift (not shown), confirming that OxyR was still reduced. These data indicate that oxidized as well as reduced OxyR binds as a tetramer, but that the conformation of the DNA-protein complexes differ.

Since the OxyR proteins of both $R$. capsulatus and $R$. sphaeroides show a high homology to each other $(43 \%$ identity, $56 \%$ similarity), we also tested the binding capacity of the R. capsulatus OxyR protein to the katE promoter region. We observed a binding of both the reduced and oxidized protein to the $k a t E$ promoter region, but no different DNA-protein complexes were observed (Fig. 6b).

In order to define the binding sites of reduced and oxidized OxyR to the kat $G$ promoter region better, we performed footprint analysis. Oxidized OxyR protein bound to AT-rich sequences close to the translational start of $o x y R$ (Fig. 6c, d). When reduced OxyR was applied, the footprint was significantly extended. A long DNA stretch comprising sequences well within the $o x y R$ gene was protected from DNaseI digestion.

\section{DISCUSSION}

$R$. sphaeroides and $R$. capsulatus are related bacteria living in the same habitats. In their natural environment, mostly lakes and ponds, they are exposed to changing light and oxygen conditions. Although the responses of the two species to changes in the environment are similar, some differences can be observed. $R$. sphaeroides harbours almost no bacteriochlorophyll under high oxygen tension, while $R$. capsulatus assembles low amounts of photosynthetic complexes. The latter strategy allows a faster adaptation to decreasing oxygen concentrations and a faster switch to anoxygenic photosynthesis when light is present. In this study, we observed a different performance of the two Rhodobacter species under peroxide stress conditions and investigated its molecular basis. Moreover, we could show that environmental stimuli influence the ability of the two Rhodobacter strains to cope with this peroxide stress.

Our results reveal that the two Rhodobacter strains show significant differences in their ability to cope with peroxide stress, which is correlated to strong differences in catalase activities. Both strains showed much faster detoxification of $\mathrm{H}_{2} \mathrm{O}_{2}$ under aerobic growth conditions than during growth under low oxygen tension, again correlating to higher catalase activities in both strains when grown under high oxygen tension. The basal expression of genes encoding catalases as determined by real-time RT-PCR was indeed higher under aerobic conditions, in both wild-type strains. Growing at high oxygen tension, bacteria will produce more ROS than during growth at low oxygen tension. Therefore, bacteria adapt to the presence of high oxygen levels by increasing the expression of genes involved in the detoxification of ROS, such as catalases. These higher expression levels result in higher resistance to peroxide stress at high oxygen levels. The assumption that the higher resistance of 
R. sphaeroides to $\mathrm{H}_{2} \mathrm{O}_{2}$ is caused by the presence of two catalases, KatE [encoded by RSP2779 (katE)] and KatC [encoded by RSP2380 (katC)] was not supported by our findings. While the expression of $k a t E$ was strongly induced by oxygen or peroxide stress, expression of katC remained unaffected (Fig. 3b, c and Fig. 4). The possibility that peroxidases could be responsible for the higher resistance of 2.4.1 can be excluded, since $R$. sphaeroides does not harbour peroxidase activity (Terzenbach \& Blaut, 1998). Hochman \& Shemesh (1987), however, observed two different peroxidase activities in $R$. capsulatus. Thus, the higher resistance of $R$. sphaeroides to peroxide stress in comparison to $R$. capsulatus is probably not due to the presence of additional enzymes, but rather to the high activity of KatE. Nevertheless, even the low expression levels of kat $\mathrm{C}$ might contribute to increase the resistance of $R$. sphaeroides to $\mathrm{H}_{2} \mathrm{O}_{2}$.

A key regulator of the response to $\mathrm{H}_{2} \mathrm{O}_{2}$ is the OxyR transcriptional regulator, which induces the expression of antioxidant activities in response to $\mathrm{H}_{2} \mathrm{O}_{2}$ stress (Storz \& Imlay, 1999). oxyR mutants of both Rhodobacter species were more sensitive to the exposure to $\mathrm{H}_{2} \mathrm{O}_{2}$ and showed slower kinetics in the detoxification of this agent compared to the parental strains, confirming a role of OxyR in the oxidative stress response of Rhodobacter. While very little detoxification of $\mathrm{H}_{2} \mathrm{O}_{2}$ was observed in strain $\mathrm{SB} o x y R$, the $R$. sphaeroides mutant 2.4.10xyR was able to detoxify $3.5 \mathrm{mM} \mathrm{H}_{2} \mathrm{O}_{2}$ within $300 \mathrm{~s}$, but with slower kinetics than the isogenic wild-type (Figs $1 \mathrm{~b}$ and $2 \mathrm{c}$ ). This indicates that OxyR is more important for defence against $\mathrm{H}_{2} \mathrm{O}_{2}$ in $R$. capsulatus than in R. sphaeroides. Unexpectedly, we found that the $\operatorname{oxy} R$ mutation resulted in a decrease of total catalase activity in both Rhodobacter species. This finding is in contrast to observations in E. coli, where the deletion of oxyR did not reduce the basal activity of catalases during exponential growth, but only in cells induced with $\mathrm{H}_{2} \mathrm{O}_{2}$ (Visick \& Clarke, 1997). The lower levels of catalase activity in strain $\mathrm{SB} o x y R$ compared to strain 2.4.10xyR are in agreement with the very poor detoxification of $\mathrm{H}_{2} \mathrm{O}_{2}$ by the $R$. capsulatus mutant. The addition of $\mathrm{H}_{2} \mathrm{O}_{2}$ to semi-aerobically grown wild-type cultures resulted in an induction of catalase activity, whereas no induction was observed in both oxyR mutants. This again is in agreement with findings in other bacterial systems, where OxyR acts as an activator of $\mathrm{H}_{2} \mathrm{O}_{2}$-inducible genes. Our observations suggest an effect of OxyR on the catalase activity in unstressed cells as well as an important role of OxyR in the adaptation of Rhodobacter to $\mathrm{H}_{2} \mathrm{O}_{2}$.

In many bacteria, genes encoding hydroperoxidases (HP) are members of the OxyR regulon. Gene expression analysis in $\operatorname{oxy} R$ mutant strains revealed that both katG of $R$. capsulatus and katE of $R$. sphaeroides are regulated by the OxyR protein. In E. coli the $k a t G$ gene is strongly induced by $\mathrm{H}_{2} \mathrm{O}_{2}$, while the katE gene is not (Schellhorn, 1994). A regulatory effect of OxyR on $k a t G$ expression has been shown for many bacteria (Loprasert et al., 2003; Ochsner et al., 2000). Our observation of fast kinetics in the induction of kat gene expression by $\mathrm{H}_{2} \mathrm{O}_{2}$ as well as the reduction $30 \mathrm{~min}$ after addition of $\mathrm{H}_{2} \mathrm{O}_{2}$ can be explained by the very fast kinetics of activation of OxyR by $\mathrm{H}_{2} \mathrm{O}_{2}$. Aslund et al. (1999) were able to examine the kinetics of OxyR oxidation and reduction in vivo and in vitro. OxyR oxidation by $\mathrm{H}_{2} \mathrm{O}_{2}$ was completed within $30 \mathrm{~s}$, and the half-time of deactivation was 10-30 min. Compared to katE and $k a t G$ expression, respectively, expression of katC was not affected by OxyR in $R$. sphaeroides. This is in agreement with results for the E. coli katE gene (Schellhorn, 1994). Both the E. coli katE gene (Schellhorn, 1994) and the $R$. sphaeroides katC gene are induced during stationary phase. The expression of the E. coli katE gene is known to be regulated by the stationary phase sigma factor RpoS, while the regulator of the $R$. sphaeroides katC gene is presently unknown. So far, no homologue of rpoS has been reported for the $\alpha$-subclass of proteobacteria, which includes the Rhodobacter species (Rava et al., 1999; Roop et al., 2003).

The $\operatorname{oxy} R$ family is widespread among prokaryotes and nearly all known $\operatorname{oxy} R$ genes share overlapping promoters with other genes (Kim \& Mayfield, 2000). The majority of genes located adjacent to $\operatorname{oxy} R$ are involved in oxidative stress protection, such as $a p h C, d p s$ and oxyS, and are regulated by OxyR (Nakjarung et al., 2003). In both Rhodobacter species the katE and $k a t G$ genes, respectively, are located adjacent to the $\operatorname{axyR}$ gene on the chromosome. Both genes are separated by approximately $100 \mathrm{nt}(\mathrm{katE} / \mathrm{oxy} R 101 \mathrm{nt}$; katG/oxyR $98 \mathrm{nt}$ ) of untranslated region and are transcribed divergently. Thus, the oxyR and katE or katG genes, respectively, share a common upstream DNA sequence and may also share cis regulatory elements. This kat/oxyR gene organization is found in many $\alpha$-proteobacteria [Rhizobium etli (del Carmen Vargas et al., 2003); Brucella abortus (Kim \& Mayfield, 2000); Agrobacterium tumefaciens (Nakjarung et al., 2003)], suggesting a general mechanism of regulation of these genes in $\alpha$-proteobacteria.

Since it is reported that the OxyR protein regulates expression of genes by direct binding to the promoter region (reviewed by Schell, 1993), we tested the ability to bind DNA of the R. capsulatus OxyR protein. The OxyR protein showed strong binding to the $k a t G$ promoter region and our data indicate that different conformations of DNA-protein complexes are formed with oxidized or reduced OxyR. Footprint analysis of the E. coli OxyR protein showed that OxyR binding is different under oxidizing and reducing conditions (Kullik et al., 1995). As described for E. coli (Kullik et al., 1995), the oxidized and reduced forms of $R$. capsulatus OxyR were predominantly tetrameric as revealed by size exclusion chromatography. As a member of the LysR family of bacterial regulators, OxyR acts as an activator of a regulon of genes and a repressor of its own expression (Storz \& Altuvia, 1994). Toledano et al. (1994), looking in E. coli, found that only oxidized OxyR binds $k a t G$, ahp $C, d p s$ and gorA promoters, whereas both the oxidized and the reduced protein bind the oxyRS promoter. They proposed that, by remodelling its DNA contacts, OxyR 
can impose opposite regulatory effects on the divergent $o x y R$ and oxyS promoters.

Our results show that oxidized as well as reduced OxyR binds to the kat $G / \operatorname{oxy} R$ promoter region, but the reduced protein makes extended contacts to the DNA compared to the oxidized protein. Our data also show that katG expression is strongly increased by $\mathrm{H}_{2} \mathrm{O}_{2}$, and that $\mathrm{H}_{2} \mathrm{O}_{2}$ leads to oxidation of the OxyR protein (Fig. 7c). Without the addition of $\mathrm{H}_{2} \mathrm{O}_{2}$, the level of kat $G$ expression is similar in the wild-type and the $\operatorname{oxyR}$ mutant. Thus OxyR acts as an activator of $k a t G$ expression in the presence of $\mathrm{H}_{2} \mathrm{O}_{2}$. We propose that this activation includes the release of OxyR from binding sites within the $o x y R$ gene. Our findings also suggest that reduced OxyR has little repressing effect on $k a t G$ expression, which is low in the absence of oxidized OxyR.

Future work will be aimed at the identification of additional OxyR-regulated genes and additional OxyR-binding sites to understand better the OxyR signalling mechanism in Rhodobacter.

\section{ACKNOWLEDGEMENTS}

This work was supported by the 'Deutsche Forschungsgemeinschaft' (Kl563/16-1), the 'Fonds der Chemischen Industrie' and the BMBF.

\section{REFERENCES}

Aslund, F., Zheng, M., Beckwith, J. \& Storz, G. (1999). Regulation of the OxyR transcription factor by hydrogen peroxide and the cellular thiol-disulfide status. Proc Natl Acad Sci U S A 96, 6161-6165.

Bradford, M. M. (1976). A rapid and sensitive method for the quantitation of microgram quantities of protein utilizing the principle of protein-dye binding. Anal Biochem 72, 248-254.

Cortez, N., Carrillo, N., Pasternak, C., Balzer, A. \& Klug, G. (1998). Molecular cloning and expression analysis of the Rhodobacter capsulatus sodB gene, encoding an iron superoxide dismutase. J Bacteriol 180, 5413-5430.

del Carmen Vargas, M., Encarnación, S., Dávalos, A., ReyesPérez, A., Mora, Y. M., Garcia-de los Santos, A., Brom, S. \& Mora, J. (2003). Only one catalase, $k a t G$, is detectable in Rhizobium etli, and is encoded along with the regulator OxyR on a plasmid replicon. Microbiology 149, 1165-1176.

Drews, G. (1983). Mikrobiologisches Praktikum. Heidelberg, Germany: Springer.

González-Flecha, B. \& Demple, B. (1997). Homeostatic regulation of intracellular hydrogen peroxide concentration in aerobically growing Escherichia coli. J Bacteriol 179, 382-388.

Gregor, J. \& Klug, G. (1999). Regulation of bacterial photosynthesis genes by oxygen and light. FEMS Microbiol Lett 179, 1-9.

Gregor, J. \& Klug, G. (2002). Oxygen-regulated expression of genes for pigment binding proteins in Rhodobacter capsulatus. J Mol Microbiol Biotechnol 4, 249-253.

Hochman, A. \& Shemesh, A. (1987). Purification and characterization of a catalase-peroxidase from the photosynthetic bacterium Rhodopseudomonas capsulata. J Biol Chem 262, 6871-6876.
Hübner, P., Willison, J. C., Vignais, P. M. \& Bickle, T. A. (1991). Expression of regulatory nif genes in Rhodobacter capsulatus. J Bacteriol 173, 2993-2999.

Keen, N. T., Tamaki, S., Kobayashi, D. \& Trollinger, D. (1988). Improved broad-host-range plasmids for DNA cloning in Gramnegative bacteria. Gene 70, 191-197.

Kim, J. A. \& Mayfield, J. (2000). Identification of Brucella abortus OxyR and its role in control of catalase expression. J Bacteriol 182, 5631-5633.

Kullik, I., Stevens, J., Toledano, M. B. \& Storz, G. (1995). Mutational analysis of the redox-sensitive transcriptional regulator OxyR: regions important for DNA binding and multimerization. J Bacteriol 177, 1285-1291.

Laemmli, U. K. (1970). Cleavage of structural proteins during the assembly of the head of bacteriophage T4. Nature 227, 680-685.

Li, K., Härtig, E. \& Klug, G. (2003a). Thioredoxin 2 is involved in oxidative stress defence and redox-dependent expression of photosynthesis genes in Rhodobacter capsulatus. Microbiology 149, 419-430.

Li, K., Pasternak, C. \& Klug, G. (2003b). Expression of the trxA gene for thioredoxin 1 in Rhodobacter sphaeroides during oxidative stress. Arch Microbiol 180, 484-489.

Loprasert, S., Whangsuk, W., Sallabhan, R. \& Mongkolsuk, S. (2003). Regulation of the $k a t G-d p s A$ operon and the importance of KatG in survival of Burkholderia pseudomallei exposed to oxidative stress. FEBS Lett 542, 17-21.

Maciver, I. \& Hansen, E. J. (1996). Lack of expression of the global regulator OxyR in Haemophilus influenzae has profound effect on growth phenotype. Infect Immun 64, 4618-4629.

Nakjarung, K., Mongkolsuk, S. \& Vattanaviboon, P. (2003). The oxyR from Agrobacterium tumefaciens: evaluation of its role in the regulation of catalase and peroxidase responses. Biochem Biophys Res Comm 304, 41-47.

Ochsner, U. A., Vasil, M. L., Alsabbagh, E., Parvatiyar, K. \& Hassett, D. J. (2000). Role of the Pseudomonas aeruginosa oxyR-recG operon in oxidative stress defense and DNA repair: OxyR-dependent regulation of katB-ankB, ahpB, and ahpC-ahpF. J Bacteriol 182, 4533-4544. Pasternak, C., Haberzettl, K. \& Klug, G. (1999). Thioredoxin is involved in oxygen-regulated formation of the photosynthetic apparatus of Rhodobacter sphaeroides. J Bacteriol 181, 100-106.

Perelman, A., Uzan, A., Hacohen, D. \& Schwarz, R. (2003). Oxidative stress in Synechococcus sp. strain PCC 7942: various mechanisms for $\mathrm{H}_{2} \mathrm{O}_{2}$ detoxification with different physiological roles. J Bacteriol 185, 3654-3660.

Pfaffl, M. W. (2001). A new mathematical model for relative quantification in real-time RT-PCR. Nucleic Acids Res 29, e45, 2001-2007.

Prentki, P., Binda, A. \& Epstein, A. (1991). Plasmid vectors for selecting IS1-promoted deletions in cloned DNA: sequence analysis of the omega interposon. Gene 103, 17-23.

Rava, P. S., Somma, L. \& Steinman, H. M. (1999). Identification of a regulator that controls stationary-phase expression of catalaseperoxidase in Caulobacter crescentus. J Bacteriol 181, 6152-6159.

Roop, R. M., 2nd, Gee, J. M., Robertson, G. T., Richardson, J. M., Ng, W. L. \& Winkler, M. E. (2003). Brucella stationary-phase gene expression and virulence. Annu Rev Microbiol 57, 57-76.

Sanger, F., Nicklen, S. \& Coulson, A. R. (1977). DNA sequencing with chain-terminating inhibitors. Proc Natl Acad Sci U S A 74, 5463-5467.

Schell, M. A. (1993). Molecular biology of the LysR family of transcriptional regulators. Annu Rev Microbiol 47, 597-626. 
Schellhorn, H. E. (1994). Regulation of hydroperoxidase (catalase) expression in Escherichia coli. FEMS Microbiol Lett 131, 113-119.

Sigaud, S., Becquet, V., Frendo, P., Puppo, A. \& Hérouart, D. (1999). Differential regulation of two divergent Sinorhizobium meliloti genes for HPII-like catalases during free-living growth and protective role of both catalases during symbiosis. J Bacteriol 181, 2634-2639.

Simon, R., Priefer, U. \& Puhler, A. (1983). In Molecular Genetics of the Bacteria-Plant Interaction, pp. 99-106. Edited by A. Puhler. Heidelberg, Germany: Springer.

Storz, G. \& Altuvia, S. (1994). OxyR regulon. Methods Enzymol 234, 217-223.

Storz, G. \& Imlay, J. A. (1999). Oxidative stress. Curr Opin Microbiol 2, 188-194.

Storz, G. \& Zheng, M. (2000). Oxidative stress. In Bacterial Stress Responses, pp. 47-59. Edited by G. Storz \& R. Hengge-Aronis. Washington, DC: American Society for Microbiology.

Terzenbach, D. P. \& Blaut, M. (1998). Purification and characterization of a catalase from the nonsulfur phototrophic bacterium Rhodobacter sphaeroides ATH 2.4.1 and its role in the oxidative stress response. Arch Microbiol 169, 503-508.
Toledano, M. B., Kullik, I., Trinh, F., Baird, P. T., Schneider, T. \& Storz, G. (1994). Redox-dependent shift of OxyR-DNA contacts along an extended DNA-binding site: a mechanism for differential promoter selection. Cell 78, 897-909.

Ueda, M., Kinoshita, H., Maeda, S. I., Zou, W. \& Tanaka, A. (2003). Structure-function study of the amino-terminal stretch of the catalase subunit molecule in oligomerization, heme binding, and activity expression. Appl Microbiol Biotechnol 61, 488-494.

van Neil, C. B. (1941). The culture, general physiology, morphology, and classification on the non-sulfur purple and brown bacteria. Bacteriol Rev 8, 1-118.

Visick, J. E. \& Clarke, S. (1997). RpoS- and OxyR-independent induction of HPI catalase at stationary phase in Escherichia coli and identification of rpoS mutations in common laboratory strains. J Bacteriol 179, 4158-4163.

Yen, H. C. \& Marrs, B. (1976). Map of genes of carotenoid and bacteriochlorophyll biosynthesis in Rhodopseudomonas capsulata. J Bacteriol 126, 619-629.

Zeilstra-Ryalls, J. H. \& Kaplan, S. (2004). Oxygen intervention in the regulation of gene expression: the photosynthetic bacterial paradigm. Cell Mol Life Sci 61, 417-436. 